\title{
Prevalence of Glucose 6 Phosphate Dehydrogenase deficiency in Eastern India, a Study from a Tertiary Care Hospital
}

\author{
Sudeb Mukherjee* \\ Department of Cardiology, Institute of Cardiovascular Science, India
}

Submission: November 3, 2017; Published: November 20, 2017

*Corresponding author: Sudeb Mukherjee Department of Cardiology, Institute of Cardiovascular Science, India, Email: drsumukherjee@gmail.com

Abstract

a. Background: Glucose 6 phosphate dehydrogenase (G6PD) deficiency is an X-linked recessive hereditary disease characterized by abnormally low levels of Glucose 6 phosphate dehydrogenase. Certain racial and ethnic groups have an increased incidence of this deficiency. This study destined to reveal the prevalence of G6PD deficiency in Eastern India population.

b. Methods: Total 250 patients (186 male and 64 female) were included in this study. They were subsequently categorized into various subgroups and analysed properly.

c. Results: G6PD deficiency was found in overall $10 \%$ of the population in this part of the world. Prevalence was higher in tribal community compared to non tribal community.

d. Conclusion: Given the large proportion of the population suffering from G6PD deficiency mass screening programme should be implemented to prevent drugs (antimalarial and others) induced unwarranted catastrophe.

Materials and Methods: The present study on incidence of Glucose 6 phosphate dehydrogenase was carried out in individuals attending the Inpatient section of the Department of Medicine in R G KAR Medical College Hospital, Kolkata. The study of glucose 6 phosphate dehydrogenase enzyme on the 250 cases admitted in this Hospital for varying reasons in the Department of Medicine was done with the help of commercially available kit for detecting erythrocyte glucose 6 phosphate dehydrogenase enzymes. This enzyme study is based on the principle of method originally devised by Kornberg and Horecker and of Lohr and Waller modified on the recommendation of the ICSH. Besides routine investigation, following investigations were also done with special attention in all cases.

i. Complete blood count.

ii. Reticulocyte count.

iii. Comment on peripheral blood smear:

iv. Quantitative estimation of Glucose 6 phosphate dehydrogenase enzyme.

Quantitative Estimation of G6PD enzyme:

a. Laboratory Procedures: This was done with the help of commercially available kit. It is a sigma procedure and is a modification of the spectrophotometric methods of Kornberg and Horecker [1], and of Lohr and Waller [2]. This involves measurement of the rate of increase in reduction of NADP to NADPH and its spectrophotometric absorbance at $340 \mathrm{~nm}$ serves to quantify enzymatic activity.

Observation \& Results: Table 1 shows that out of total no. of cases studied $(n=250)$, the maximum incidence was observed in 21-40 years of age group (49.2\%). The age of cases studied varies from 14 years to 60 years. Table 2 shows that out of total no. of cases studied $(n=250), 74.4$ $\%$ were males while $25.6 \%$ were females. The maximum incidence was observed in 21-40 years of age (49.2\%). Table 3 shows that among the total no. of males $55 \%$ belonged to Tribal community while $45 \%$ belonged to Non-tribal community. Among the females $36 \%$ belonged to Tribal community while $64 \%$ belonged to Non-tribal community. The incidence of G6PD deficiency in the selected sample frame of cases was $10 \%$, details of which have been shown in (Table 4). Comparison of G6PD activity between the Tribal and Non-tribal population showed that $60 \%$ of G6PD deficient cases belong to the Tribal community while the rest $40 \%$ belong to the Non-tribal community (Table 5). Further analysis regarding gender distribution in different communities has been shown in Table 6 and Table 7.

Discussion: In India Chatterjee et al. (1961) worked on mixed Indian population and investigated for enzyme Glucose 6 phosphate dehydrogenase deficiency and reported the incidence of 5\% in Konkan Hindus and Parsis, 5\% in Bengalis, 6\% in Muslims, 8\% in Nepalese and $11 \%$ in Uttar Pradesh and Bihar including Jharkhand [3]. Thirteen biochemically characterized variants have been reported from India. At the 


\section{Juniper Online Journal of Public Health}

molecular level, G6PD Mediterranean is the most common deficient variant in the caste groups whereas, G6PD Orissa is more prevalent among the tribal of India. The third common variant seen in India is G6PD Kerala-Kalyan.

Bhasin and Walter reviewed the prevalence and distribution of Glucose 6 phosphate dehydrogenase deficiency in India by pooling data from 224 different studies based on geographical, occupational, ethnic and linguistic categories. Higher prevalence was reported from North and West than South India [4]. Studies from the Eastern parts of India were few. In Southern India only tribals of Tamil Nadu and Andhra Pradesh show high prevalence. The occupational groups did not show any difference in the incidence of Glucose 6 phosphate dehydrogenase deficiency. The frequency is higher among the tribal than the caste populations. Generally the Austro-Asiatic and Indo-European language groups show higher prevalence compared to the Dravidian language speaking groups. The highest frequency (27.94\%) of Glucose 6 phosphate dehydrogenase enzyme deficiency has been reported from Surat, Gujarat. The Parsi population of Mumbai also shows high frequency. High prevalence in tribes can be explained in terms of the geographical spread of malaria [5]. The age of subjects range from 14-60 years with maximum number of subjects in the age group of 21-40 years similar distribution was noted in some of the hospital based studies [6,7].

Sex distribution of subjects under study revealed $74.4 \%(n=186)$ were male, while $25.6 \%$ were females. Such male bias is well known due to outdoor nature. The study shows that incidence of Glucose 6 phosphate dehydrogenase deficiency is $10 \%$. It showed that $60 \%$ of G6PDdeficient cases belong to the tribal community while the rest $40 \%$ belong to the non-tribal community. This is consistent with the higher incidence of G6PD and other genetic disorders seen in tribal population of India according to several studies [8]. This clustering of genetic disorders in the tribal population may be due to the inbreeding that still occurs in such populations.

$80 \%$ of the G6PD deficient were males. This is consistent with several studies conducted for glucose 6 phosphate dehydrogenase enzyme deficiencies. It is due to the $\mathrm{X}$-linked nature of this genetic disorder. Heterozygous males manifest the disorder while females who are homozygous usually manifest the disorder and heterozygous females remain carriers. Fortunately, most of the G6PD deficient person will remain clinically asymptomatic throughout their lives.

However, a proportion of glucose 6 phosphate dehydrogenase deficient individuals develop neonatal jaundice or acute hemolytic anemia, which, if managed inadequately, can cause death or permanent neurological damage. The highest frequencies of glucose 6 phosphate dehydrogenase deficiency are in tropical Africa and tropical and subtropical Asia, which are also malaria-endemic areas. In areas of high incidence, clinicians and patients must be alert and prepared to avoid any factors that might trigger severe clinical manifestations of the deficiency. In the present study conducted in my hospital it was seen that the incidence of glucose 6 phosphate dehydrogenase enzyme deficiency was $10 \%$. On comparing the incidence between tribal and non-tribal population in the study, it was seen that the incidence was comparatively higher in the tribal population.

Therefore to conclude When clinical and hematological findings raise the suspicion of glucose 6 phosphate dehydrogenase deficiency, the disorder should be confirmed by quantitative spectrophotometric measurement of red blood cell enzyme activity. There is also need for a large screening programme, especially in malaria endemic zones, where due to natural selection of population, there seems to be a higher incidence of glucose 6 phosphate dehydrogenase enzyme deficiency, which gives protection against severe malaria. Such screening programmes can be done using the rapid fluorescent spot test initially, after which findings can be confirmed by a quantitative assay if necessary.

Keywords: Glucose 6 phosphate dehydrogenase (G6PD); Tribal and nontribal community; Malaria

Table 1: Age Distribution of Cases under Study ( $n=250)$.

\begin{tabular}{|c|c|c|}
\hline $\begin{array}{c}\text { Age group } \\
\text { In years }\end{array}$ & $\begin{array}{c}\text { Total no. of cases in different age } \\
\text { Groups }\end{array}$ & $\begin{array}{c}\text { Percentage } \\
\%\end{array}$ \\
\hline $14-20$ YEARS & 30 & $49.2 \%$ \\
\hline $21-40$ YEARS & 123 & $38.8 \%$ \\
\hline $41-60$ YEARS & 97 & 100 \\
\hline TOTAL & 250 & \\
\hline
\end{tabular}

Table 2: Sex Distribution of Cases under Study $(n=250)$.

\begin{tabular}{|c|c|c|c|c|c|}
\hline $\begin{array}{c}\text { Age group } \\
\text { In years }\end{array}$ & $\begin{array}{c}\text { Total no. of cases } \\
\text { In different age } \\
\text { Groups }\end{array}$ & $\begin{array}{c}\text { No. of } \\
\text { Males }\end{array}$ & $\begin{array}{c}\text { No. of } \\
\text { Females }\end{array}$ & $\begin{array}{c}\% \text { of } \\
\text { Males }\end{array}$ & Females \\
\hline $14-20$ YEARS & 30 & 19 & 11 & $10.22 \%$ & $17.19 \%$ \\
\hline $21-40$ YEARS & 123 & 93 & 30 & $50.0 \%$ & $46.88 \%$ \\
\hline $41-60$ YEARS & 97 & 74 & 23 & $39.78 \%$ & $35.94 \%$ \\
\hline TOTAL & 250 & 186 & 64 & 100 & $100(25.60 \%)$ \\
\hline
\end{tabular}




\section{Juniper Online Journal of Public Health}

Table 3: Sex distribution of the community (tribal/non-tribal) to which the cases under study belong.

\begin{tabular}{|c|c|c|c|c|c|}
\hline \multirow{2}{*}{ Community } & $\begin{array}{c}\text { Total no. of } \\
\text { cases in each } \\
\text { community }\end{array}$ & No. of & No. of & Females & Males \\
\hline TRIBAL & 125 & 102 & 23 & $54.84 \%$ \\
\hline NON-TRIBAL & 125 & 84 & 41 & $45.16 \%$ \\
\hline TOTAL & 250 & 186 & 64 & $74.40 \%$ \\
\hline
\end{tabular}

Table 4: Incidence of glucose 6 phosphate dehydrogynase deficiency in the sample frame.

\begin{tabular}{|c|c|c|}
\hline G6pd enzyme activity & Total no. of Cases & Percentage \% \\
\hline $\begin{array}{c}\text { NORMAL ACTIVITY } \\
(4.6-13.5 \mathrm{U} / \mathrm{gm} \mathrm{Hb})\end{array}$ & 225 & $90.0 \%$ \\
\hline $\begin{array}{c}\text { LOW ACTIVITY } \\
(<4.6 \mathrm{U} / \mathrm{gm} \mathrm{Hb})\end{array}$ & 25 & $10.0 \%$ \\
\hline TOTAL & 250 & 100 \\
\hline
\end{tabular}

Table 5: Comparison between Different Communities (Tribal/Nontribal) Of Incidence Of Glucose 6 Phosphate Dehydrogenise Deficiency In The Sample Frame.

\begin{tabular}{|c|c|c|c|c|c|}
\hline Community & $\begin{array}{l}\text { Total no. of } \\
\text { cases } \\
\text { In each } \\
\text { Community }\end{array}$ & $\begin{array}{l}\text { Normal g6pd } \\
\text { activity }\end{array}$ & $\begin{array}{l}\text { Low g6pd } \\
\text { activity }\end{array}$ & $\begin{array}{c}\text { \% With normal } \\
\text { g6pd }\end{array}$ & $\begin{array}{c}\text { \% with low } \\
\text { g6pd }\end{array}$ \\
\hline TRIBAL & 125 & 110 & 15 & $48.89 \%$ & $60 \%$ \\
\hline NON-TRIBAL & 125 & 115 & 10 & $51.11 \%$ & $40 \%$ \\
\hline TOTAL & 250 & 225 & 25 & 100 & 100 \\
\hline
\end{tabular}

Table 6: Sex distribution of the tribal community under study with glucose 6 phosphate dehydrogenase deficiency. Sex Total no. of cases with low

\begin{tabular}{|c|c|c|}
\hline Sex & $\begin{array}{c}\text { Total no. of cases with low } \\
\text { G6pd activity (<4.6 u/gm hb) }\end{array}$ & Percentage \% \\
\hline MALE & 12 & $80 \%$ \\
\hline FEMALE & 3 & $20 \%$ \\
\hline TOTAL & 15 & 100 \\
\hline
\end{tabular}

Table 7: Sex distribution of the non-tribal community under study with glucose 6 phosphate dehydrogenase deficiency.

\begin{tabular}{|c|c|c|}
\hline Sex & $\begin{array}{c}\text { Total no. of cases with low } \\
\text { G6pd activity (<4.6 u/gm hb) }\end{array}$ & Percentage \% \\
\hline MALE & 8 & $80 \%$ \\
\hline FEMALE & $20 \%$ & 10 \\
\hline TOTAL & 100 \\
\hline
\end{tabular}

\section{Introduction}

Glucose 6 phosphate dehydrogenase (G6PD) deficiency is an X-linked recessive hereditary disease characterized by abnormally low levels of G6PD, a metabolic enzyme involved in the pentose phosphate pathway, which is especially important in erythrocyte metabolism. G6PD deficiency is the most common human enzyme defect being present in more than 400 million people worldwide. African, Middle Eastern, Indian Subcontinent and South East Asian people are affected the most along with those who are mixed with any of the above [9]. All humans have the Glucose 6 phosphate dehydrogenase gene. Some people are

born with a mutation of the Glucose 6 phosphate dehydrogenase gene. Most of these individuals are asymptomatic but may exhibit non-immune hemolytic anemia, even severe anemia in response to exposure to certain environmental triggers, most commonly, infection or exposure to certain foods like fava beans (favism), medications or chemicals [10].

Glucose 6 phosphate dehydrogenase deficiency is an X-linked recessive genetic phenomenon. So the symptomatic patients are 
almost exclusively male, due to the X-linked recessive nature of inheritance, but female carriers can be clinically affected due to unfavorable lionization [11]. Certain racial and ethnic groups have an increased incidence of this deficiency. Glucose 6 phosphate dehydrogenase deficiency does differ among populations. It is found generally in people whose ancestors have come from areas where malaria has been common, such as the Mediterranean region, Africa and South East Asia [12]. Apart from study done by Baxim and Chatterjee et al. [3] there is no recent study to reveal the prevalence of G6PD deficiency in eastern India so far. In the present hospital based study - the aim is to make a comparative study of incidence of Glucose 6 phosphate dehydrogenase deficiency in West Bengal between tribals and non-tribals.

\section{References}

1. Kornberg A, Horecker ABL (1955) G6PD in methods in Enzymology. SP Colowick, N 0 Kaplan, Editors, Academic Press, New York 1: 323.

2. Lohr GW, Waller HD (1961) The enzyme deficient hemolytic anemia. German Medical Monthly 6: 37.

3. Chatterjee B, Swarup S, Ghosh SK (1963) Instability of reduced glutathione and deficiency of G6PD activity of red cells in normal Indian. Bull Calcutta School Trop Med 10: 162-163.
4. MK Bhasin, H Walter (2001) Genetic of Caste and Tribes of India, KamlaRaj Enterprises, India.

5. Chatterjee JB (1966) Hemoglobinopathies, G6PD deficiency and allied problems in the Indian Sub-continent. Bull WHO 35(6): 837-856.

6. SC Gupte, AN Shaw, KC Shah (2005) Hematological findings and severity of G6PD deficiency in Vataliya Prajapati subjects. Journal of Association of Physicians of India 53: 1027-1030.

7. TP Sharma, Rajkumari (2010) Glucose-6-phosphate dehydrogenase deficiency in Danguria Tharu settled in Baharaich district of Uttar Pradesh. The Anthropologist 12(1): 59-61.

8. RS Balgir (2007) Genetic burden of red cell enzyme glucose-6phosphate dehydrogenase deficiency in two major Scheduled Tribes of Sundargarh district, Northwestern Orissa, India. Current Science 92(6): 768-774.

9. Ruwende C, Hill A (1998) Glucose-6-phosphate dehydrogenase deficiency and malaria. J Mol Med (Berl) 76: 581-588.

10. Beutler E (1967) G6PD deficiency, Diagnosis, clinical and genetic implications. Am J Clin Path 47(3): 303-311.

11. Beutler E, Yeh M, Fairbanks VF (1962) The normal human female as a mosaic of X-chromosome activity: studies using the genes of G6PDH deficiency as a marker. Proc Natl Acad Sci, USA 48(1): 9-16.

12. Geneva: World Health Organization (WHO) (2015). World malaria report.

\section{Your next submission with Juniper Publishers will reach you the below assets}

- Quality Editorial service

- Swift Peer Review

- Reprints availability

- E-prints Service

- Manuscript Podcast for convenient understanding

- Global attainment for your research

- Manuscript accessibility in different formats

( Pdf, E-pub, Full Text, Audio)

- Unceasing customer service

Track the below URL for one-step submission

https://juniperpublishers.com/online-submission.php 